\title{
Okoljevarstvena psihologija kot raziskovalno področje
}

Polona Kalc* Sežana

Povzetek: V zadnjih desetletjih narašča zavedanje o pomenu vpletenosti psihologije v okoljevarstveno problematiko. Na prelomu tisočletja se je oblikovalo novo raziskovalno področje, in sicer t. i. okoljevarstvena psihologija, katere namen je združevanje spoznanj temeljnih psiholoških panog s področja okoljevarstva in trajnostnega razvoja ter nadaljnjega bazičnega in aplikativnega raziskovanja na omenjenih področjih. Okoljevarstvena psihologija je novejša izpeljanka okoljske psihologije, s katero tvorita 34. oddelek Ameriškega psihološkega združenja (APA). Kljub porastu števila spoznanj z raziskovalnega področja okoljevarstvene psihologije le-ta v Sloveniji ni širše prepoznana in priznana, zato je glavni namen tega prispevka slovenske psihologe seznaniti z okoljevarstveno psihologijo kot raziskovalnim področjem znotraj temeljnih panog psihologije.

Ključne besede: okoljevarstvena psihologija, okoljevarstvo, raziskovalno področje

\section{Conservation psychology as a field of study}

Polona Kalc

Sežana, Slovenia

\begin{abstract}
During the past decades the importance of psychology has become more prominent when addressing environmental issues. At the turn of the millennium a new field of psychological research was introduced to scientific community. The so-called conservation psychology strives to merge and spur basic and applied psychological research from the field of (pro)environmental behaviour and sustainable development. Together with environmental and population psychology, it forms Division 34 of American Psychological Association. However, conservation psychology is not a broadly known and renowned field of study in Slovenia. Therefore, the main purpose of the present article is to introduce conservation psychology as a possible field of study to Slovenian psychologists.
\end{abstract}

Keywords: conservation psychology, environmentalism, field of study 
Na svetu je znanih približno dva milijona živalskih in 280.000 rastlinskih vrst (Gabrovšek, 2011). Njihova številčnost se iz leta v leto drastično zmanjšuje predvsem zaradi ene same vrste - človeške. Skrb za ohranjanje biotske raznovrstnosti in naravnega okolja že dolgo ni zgolj domena varstvene biologije. Vse več avtorjev (npr. Mascia idr., 2003; Oskamp, 2000) se namreč zaveda, da je zaradi človekove odgovornosti za uničevanje narave okoljsko vprašanje še kako pereč družbeni problem, $\mathrm{k}$ osvetljevanju katerega lahko pomembno doprinese prav družboslovje. To spoznanje je botrovalo hitremu vzponu okoljevarstvene psihologije (angl. conservation psychology).

Čeprav okoljevarstvena psihologija že nekaj let skupaj s populacijsko in okoljsko psihologijo tvori 34. oddelek Ameriškega psihološkega združenja (APA), je v Sloveniji manj zastopana oz. ni širše prepoznana kot raziskovalno področje. $\mathrm{V}$ prispevku poskušam opredeliti njeno (raziskovalno) področje in jo obenem razločiti od okoljske psihologije. Nadalje pa predstavljam nekaj raziskovalnih izhodišč $\mathrm{v}$ socialni in razvojni psihologiji $\mathrm{z}$ namenom spodbujanja raziskav na področju okoljevarstvene psihologije v Sloveniji.

\section{Umestitev in opredelitev okoljevarstvene psihologije}

Konec devetdesetih let prejšnjega stoletja in v začetku 21. stoletja se je s porastom zaskrbljenosti zaradi okoljske problematike začel povečevati tudi raziskovalni interes psihologov za to področje (Clayton in Saunders, 2012). $\mathrm{Na}$ Mednarodnem simpoziju o družbi in upravljanju virov (ISSRM) leta 2000 so mnogi raziskovalci, ki so se ukvarjali s proučevanjem odnosa med človekom in naravo s poudarkom na spodbujanju okolju prijaznega vedenja, izrazili željo po večji povezanosti in krepitvi skupne identitete, $\mathrm{k}$ čemur bi lahko pripomoglo oblikovanje novega raziskovalnega področja $\mathrm{v}$ psihologiji (Brook, 2001). Ob dolgoletni tradiciji okoljske psihologije se je porajal dvom o smiselnosti uvajanja novega področja. Mnogi razpravljavci so soglašali, da je okoljska psihologija preširok pojem za označevanje njihovega raziskovalnega interesa (Brook, 2001). Po njihovem mnenju naj bi bila preveč vezana na urbano okolje in $\mathrm{v}$ ospredje postavljala vpliv fizičnega okolja na človeka, poleg tega pa naj ne bi omogočala zadostne povezanosti med psihološkimi panogami. Okoljska psihologija naj bi namreč kot uveljavljena psihološka panoga omejevala možnost vključevanja spoznanj iz raziskovalnih področij drugih psiholoških disciplin (Brook, 2001). Glede na izrazito medsebojno prepletenost psiholoških panog je zadnji argument sicer manj prepričljiv, a je na koncu prevladala težnja po večji možnosti mreženja psihologov, ki jih v raziskovanje vodi (tudi) skrb za naravo.
Po vzoru varstvene biologije je vzniknila ideja o okoljevarstveni psihologiji ${ }^{1}$, ki jo je C. Saunders (2003) definirala kot »znanstveno proučevanje vzajemnega odnosa med človekom in ostalo naravo s poudarjeno težnjo po ohranjanju naravnega okolja» (str. 138). Okoljevarstvena psihologija ni nova psihološka panoga, temveč si jo je bolje zamišljati kot raziskovalno področje ${ }^{2}$ (Clayton in Saunders, 2012; Saunders, 2003). Njen predmet proučevanja je recipročni odnos med človekom in naravo, njen cilj pa spodbujanje varovanja naravnega okolja (Saunders, 2003).

C. Saunders (2003) si okoljevarstveno psihologijo predstavlja kot »super področje« sodelovanja in mreženja raziskovalcev in ostalih strokovnjakov, ki se v raziskovanju in delu zavzemajo za ohranjanje narave in trajnostni razvoj. V »mrežo« zajema različne psihološke panoge in smeri (okoljsko, socialno, razvojno, kognitivno, klinično, zdravstveno, pozitivno, transpersonalno psihologijo, ekopsihologijo, psihologijo delain organizacije, psihologijo porabnika, psihologijo skupnosti, psihofiziologijo) kot tudi nekatera področja drugih ved (ekologija človeka in okoljska sociologija).

Med omenjenimi psihološkimi panogami je okoljevarstveni psihologiji najsorodnejša okoljska psihologija (Saunders, 2003), vendar med njima obstajajo nekatere razlike. Okoljska psihologija je psihološka panoga, ki proučuje odnos med posameznikom in fizičnim okoljem (Gifford, 2002), pri čemer jo zanimata tako umetno oblikovano kot naravno okolje, medtem ko je okoljevarstvena psihologija raziskovalno področje, ki se osredotoča le na naravno okolje (Clayton in Brook, 2005; Saunders, 2003) in je za razliko od okoljske psihologije izraziteje okoljevarstveno naravnana (Saunders, 2003). Njuni raziskovalni področji se torej deloma prekrivata. Lahko bi rekli, da je del okoljevarstvene psihologije okoljska psihologija in da je tudi okoljska psihologija del okoljevarstvene psihologije (a ne vsa) (Clayton in Saunders, 2012), kar si lahko najbolje predstavljamo v obliki Vennovega diagrama, ki ima v preseku raziskovanje človekovega odnosa do narave, v samostojnih delih pa imata okoljska in okoljevarstvena psihologija ločene raziskovalne interese (npr. okoljska psihologija zajema proučevanje urbanega okolja in njegovih neživih dejavnikov, okoljevarstveno psihologijo pa na primer zanima razvoj okoljske identitete).

\footnotetext{
${ }^{1}$ Medtem ko je za varstveno biologijo glavno področje proučevanja biotska raznovrstnost, se okoljevarstvena psihologija osredotoča na širši spekter okoljevarstvenih tem (poleg ohranjanja biodiverzitete tudi podnebne spremembe, skrb za naravne vire itd.).

${ }^{2}$ Sommer (2000) razlikuje med psihološko panogo (angl. subdiscipline) in raziskovalnim področjem (angl. field of study). Medtem ko je za prvo značilno, da so strokovnjaki in raziskovalci zaključili študij psihologije, so na področju raziskovanja prisotni strokovnjaki iz različnih panog in/ali znanstvenih disciplin, ki se osredotočajo na skupen problem.
} 
Okoljevarstvene psihologije prav tako ne smemo zamenjevati z ekopsihologijo, čeprav se omenjeni področji deloma prekrivata. Tako okoljevarstveno psihologijo kot ekopsihologijo zanima odnos med posameznikovo povezanostjo $\mathrm{z}$ naravo in njegovim blagostanjem. $Z$ večjo človekovo povezanostjo z naravo naj bi se namreč povečala tudi posameznikova skrb za varovanje okolja (Blair, 2011). Glavna razlika med področjema je v poudarku na znanstvenem proučevanju, ki je v ospredju okoljevarstvene psihologije. Medtem ko ekopsihologija združuje globoko ekologijo in transpersonalno psihologijo ter v nasprotju z okoljevarstveno psihologijo sega v spiritualistične vode (Hoelterhoff, 2010), je okoljevarstvena psihologija nastala (tudi) kot odgovor na premalo znanstveno rigorozno usmeritev ekopsihologije (Brook, 2001).

Okoljevarstvena psihologija združuje temeljna psihološka spoznanja in teorije različnih psiholoških panog ter uporablja psihološke raziskovalne metode (kvalitativne, kvantitativne, eksperimentalne in korelacijske metode) pri naslavljanju okoljevarstvenih vprašanj (Saunders, 2003). $\mathrm{V}$ ospredje postavlja aplikativno raziskovanje, a je njena domena tudi bazično naravnana (Clayton in Myers, 2009; Saunders, 2003). Med raziskovalnimi temami, ki zanimajo okoljevarstvene psihologe, so na primer napovedniki okolju (ne)prijaznega vedenja, stališča in prepričanja o naravi ter vpliv vrednot, razvijanje posameznikove skrbi za okolje in razvoj okoljske identitete, odnosi med ljudmi in živalmi, odnos med psihološko povezanostjo $\mathrm{z}$ naravo in trajnostno naravnanostjo, pomen pomembnih življenjskih dogodkov za razvoj posameznikove skrbi za okolje, moralno presojanje $\mathrm{v}$ povezavi $\mathrm{z}$ naravnim okoljem, empatija do ostalih živih bitij, dojemanje tveganja, razreševanje konfliktov, pomen posameznikove izpostavljenosti naravnemu okolju ... (Ameriško psihološko združenje [APA], 2015).

Raziskovalne teme je S. Clayton s sodelavci (2015) zajela $\mathrm{v}$ tri nadredne kategorije raziskovanja odnosov med človekom in naravo, ki jih je opredelila kot proučevanje (a) vedenja, (b) dojemanja in (c) blagostanja, ter predlagala nekatere psihološke panoge, ki bi se z omenjenimi področji lahko ukvarjale. Prva kategorija zajema raziskovanje in spodbujanje okolju prijaznega vedenja, s čimer naj bi se ukvarjale socialna psihologija, okoljska psihologija ter psihologija dela in organizacije. Na področju dojemanja naj bi se aktivirali kognitivni in socialni psihologi, ki bi proučevali razumevanje naravnih procesov in $\mathrm{Z}$ njimi povezano dojemanje tveganja. $\mathrm{Z}$ raziskovanjem vplivov okolja na človeka in njegovo blagostanje pa naj bi se ukvarjale klinična psihologija, razvojna psihologija, socialna psihologija in psihologija skupnosti. K zadnjemu področju bi lahko dodali še pozitivno psihologijo, spoznanja iz razvojne psihologije pa bi lahko prispevala tudi k področju spreminjanja vedenja.

$\mathrm{V}$ dosedanjem raziskovanju in delu na področju okoljevarstvene psihologije sta najpogosteje zastopani okoljska in socialna psihologija, nezanemarljiv pa je tudi vpliv razvojne psihologije. V nadaljevanju prispevka zato predstavljam rezultate dosedanjega raziskovanja $\mathrm{v}$ okviru socialne (s prepletom okoljske) in razvojne psihologije, pri čemer sem se zaradi obilice raziskav osredotočila predvsem na metaanalitične študije. Predstavljam tudi nekatere rezultate raziskav, ki od prevladujočih smernic nekoliko odstopajo, vključila pa sem tudi obširnejšo slovensko raziskavo, ki jo lahko kot prvo takih v Sloveniji umestimo na področje varstvene psihologije.

\section{Okoljevarstvena psihologija v socialni (in okoljski) psihologiji}

Socialna psihologija je ena od najbolj relevantnih psiholoških panog, ki skušajo razumeti in do neke mere spremeniti človekov odnos do naravnega okolja. Okoljevarstvena psihologija iz socialne psihologije prevzema spoznanja o prepričanjih, svetovnih nazorih, stališčih do narave in njihovi napovedni moči okolju prijaznega vedenja (pregled $\mathrm{v}$ Gifford in Sussman, 2012). Zanima jo tudi vpliv vrednot na vedenje do okolja (pregled v Steg in de Groot, 2012), pomen okoljske identitete za okolju prijazno vedenje (pregled v Clayton, 2012a; Clayton in Myers, 2009) in normativno vplivanje na okolju prijazno vedenje (npr. Cialdini, 2003; Goldstein, Cialdini in Griskevicius, 2008; Göckeritz idr., 2010).

Med najpogosteje navajanimi in uporabljenimi teoretičnimi modeli $\mathrm{v}$ raziskavah o spodbujanju okolju prijaznega vedenja so Ajzenova teorija načrtovanega vedenja (1991), Schwartzov model aktivacije norm (1977, v Onwezen, Antonides in Bartels, 2013) in teorija vrednot, prepričanj in norm (Stern, Dietz, Abel, Guagnano in Kalof, 1999). Nekoliko manj sta kljub svoji relevantnosti zastopani teorija socialne identitete (Tajfel, 1982, v Castro in Lima, 2001) in socialno kognitivna teorija (Bandura, 1986, v Sawitri, Hadyanto in Hadi, 2015).

Na področju stališč do okolja, ki so definirana kot skrb za okoljske probleme, so se avtorji v preteklosti ukvarjali predvsem $\mathrm{z}$ njihovo povezanostjo s sociodemografskimi spremenljivkami (pregled v Gifford in Sussman, 2012). V zadnjem obdobju nastopajo stališča le kot ena od mnogih spremenljivk v raziskavah o okolju prijaznem vedenju.

Pri merjenju stališč in sorodnih socialnopsiholoških konstruktov (npr. prepričanj in nazorov) na področju okoljske in okoljevarstvene psihologije prihaja do nekonsistentnosti na metodološkem področju. Mnogi raziskovalci namreč v namene svojih raziskav ustvarjajo nove merske instrumente, kar otežuje primerjavo rezultatov med študijami (Gifford in Sussman, 2012), zato S. Clayton (2012b) izpostavlja pomen uporabe že obstoječih validiranih merskih inštrumentov namesto »ad hoc« sestavljenih pripomočkov, ki mnogokrat ne nudijo bistvenih prednosti pri proučevanju posameznih konstruktov. $\mathrm{V}$ nadaljevanju predstavljam štiri od bolj relevantnih merskih pripomočkov (s področja prepričanj, stališč, vrednot in okoljske identitete), ki bi jih bilo po mojem mnenju dobro prirediti in validirati v slovenskem prostoru. 
Med pogosteje uporabljanimi pripomočki za merjenje stališč do okolja je Lestvica nove ekološke paradigme (New ecological paradigm scale [NEP]; Dunlap, Van Liere, Mertig in Emmet Jones, 2000), ki je prenovljena različica instrumenta »Nova okoljska paradigma« (The new environmental paradigm [NEP]; Dunlap in Van Liere, 1978). Lestvica v 15 postavkah (npr. Ljudem je namenjeno, da obvladujejo naravo, Naravno ravnotežje je krhko in ga je mogoče zlahka porušiti.) na 5-stopenjski Likertovi lestvici po navedbah avtorjev meri prepričanja, ki so del antiantropocentričnega svetovnega nazora. Kljub njunem zatrjevanju, da gre za mero prepričanj, se $\mathrm{V}$ zvezi z lestvico pogosto omenja različne konstrukte (npr. okoljska stališča, ocenjevanje zavedanja posledic okoljskih problemov in celo okoljske vrednote), ki naj bi jih le-ta merila, zato na področju vlada terminološkokonceptualna zmeda (Castro, 2006). L. Hawcroft in Milfont (2009) sta v metaanalizi raziskav, v katerih so avtorji uporabili katero od NEP lestvic, odkrila izrazito raznolikost $\mathrm{v}$ načinu aplikacije merskega pripomočka (prirejanje in spreminjanje števila postavk, diferenciacija merske lestvice), zaradi česar so bili rezultati težko primerljivi.

Milfont in Duckitt (2010) sta v odziv na mersko zmedo na področju okoljskih stališč zasnovala Vprašalnik stališč do okolja (Environmental attitudes inventory; EAI), ki temelji na močni psihometrični podlagi, saj izhaja iz večjega števila do tedaj uporabljenih vprašalnikov, stališčnih lestvic in podlestvic s področja človekovega odnosa do naravnega okolja. Vprašalnik je sestavljen iz 120 postavk, ki se združujejo v 12 lestvic, te pa v dva podfaktorja (ohranjanje in koriščenje) in nato $\mathrm{v}$ skupen faktor stališč do naravnega okolja. Njegovi prednosti naj bi bili kulturna nepristranskost in relativna »odpornost« na socialno zaželeno odgovarjanje (Milfont in Duckitt, 2010). Avtorja sta izdelala tudi dve krajši različici vprašalnika; eno z 72, drugo pa s 24 postavkami. Različica z 72 postavkami (EA-S) ima zadovoljive merske značilnosti $(\alpha$ $=0,53-0,92 ; M=0,82$ ), nekoliko nizko notranjo zanesljivost ima le ena od lestvic. Najkrajša različica (EA-24) je bila uporabljena le pri vzorcu novozelandskih študentov, kjer se je izkazala kot zadovoljiva mera splošnih okoljskih stališč in obeh podfaktorjev (Milfont, 2009, v Milfont in Duckitt, 2010).

$\mathrm{Na}$ področju ocenjevanja vrednot $\mathrm{v}$ povezavi z okolju prijaznim vedenjem so raziskovalci večinoma izhajali iz Schwartzove teorije vrednot (1994) . V njej so biosferične vrednote, ki v ospredje postavljajo skrb za okolje in naravo, zastopane le v manjši meri, zaradi česar je biosferično vrednotno naravnanost na podlagi Schwartzove teorije teže razločiti od altruističnih vrednot (de Groot in Steg, 2008; Steg in de Groot, 2012). J. de Groot in L. Steg (2008) sta $\mathrm{z}$ izdelavo novega merskega instrumenta $\mathrm{z}$ večjim številom postavk o pomenu okoljskih vrednot za posameznika od altruističnih vrednot uspeli razločiti faktor biosferičnih vrednot. Le-te uspešneje napovedujejo okoljska prepričanja, stališča in okolju prijazno vedenje kot altruistične vrednote. Omenjeni instrument, s katerim na 9-stopenjski lestvici v 13 postavkah ocenjujemo izraženost treh vrednotnih naravnanosti (egoistične, altruistične in biosferične), je kasneje L. Steg s sodelavkami dopolnila s tremi postavkami o hedonističnih vrednotah in ugotovila, da je hedonistična vrednotna naravnanost pomembnejši napovednik okolju neprijaznega vedenja kot egoistična vrednotna naravnanost (Steg, Perlaviciute, Van der Werff in Lurvink, 2014). Zaradi splošnih hedonističnih teženj vsakega posameznika bi bilo v prihodnje smiselno raziskati različne okoliščine, $\mathrm{v}$ katerih prihaja do konflikta biosferičnih in preostalih vrednot ter proučiti izide tovrstnih konfliktov, poleg tega pa primanjkuje raziskav tudi na področju utrjevanja biosferičnih vrednot, ki bi posredno ali neposredno spodbudile okolju prijazno vedenje (Steg in de Groot, 2012).

Rezultati sklopa novejših raziskav pri vzorcu nizozemskih študentov kažejo, da so biosferične vrednote $\mathrm{z}$ okolju prijaznim vedenjem (oz. namerami za okolju prijazno vedenje) posredno povezane prek okoljske identitete, ki jo lahko krepimo z opozarjanjem na posameznikova pretekla okolju prijazna vedenja (Van der Werff, Steg in Keizer, 2014). S. Clayton (2003, v Clayton, 2012a) opredeljuje okoljsko identiteto kot dojemanje samega sebe povezanega $\mathrm{z}$ naravnim okoljem $\mathrm{v}$ prepričanju, da je naravno okolje pomembno in je hkrati pomemben del posameznikovega sebstva. $\mathrm{V}$ namene merjenja posameznikove okoljske identitete je zasnovala Lestvico okoljske identitete (Enironmental identity scale; Clayton, 2003), ki zajema 24 postavk o posameznikovi povezanosti $\mathrm{Z}$ naravo in dojemanju pomembnosti naravnega okolja za lastno identiteto. Lestvica se pričakovano povezuje z okoljskimi stališči, biosferičnimi vrednotami in svetovnimi nazori (Clayton, 2003, v Clayton, 2012a). Na področju okoljske identitete ostaja še veliko odprtih vprašanj, na katera lahko poleg socialne psihologije odgovarjajo tudi kognitivna, pozitivna in razvojna psihologija. $\mathrm{V}$ okviru socialne psihologije bi bilo dobro osvetliti znotraj- in medskupinske procese pri oblikovanju skupne okoljske identitete, proučevanje v okviru kognitivne psihologije pa bi lahko omogočilo večji vpogled v vpliv okoljske identitete na spoznavne procese (Clayton, 2012a). Smiselno bi bilo spodbuditi dodatne raziskave o krepitvi okoljske identitete pri posameznikih. Kot eno od možnosti predlagam pozitivno psihologijo, v okviru katere bi lahko preverjali vpliv zanosa med aktivnostmi v naravi na krepitev okoljske identitete.

Večina dosedanjih raziskav se ločeno ukvarja bodisi s socialnopsihološkimi konstrukti in njihovo povezanostjo z okolju prijaznim vedenjem bodisi gre za (kvazi) eksperimentalne študije vplivanja na okolju prijazno vedenje. K. Polajnar Horvat (2014) je v Sloveniji izvedla eno prvih raziskav, ki bi jo lahko umestili na raziskovalno področje okoljevarstvene psihologije, in $\mathrm{v}$ njej zajela tako preverjanje socialnopsiholoških konstruktov (stališča, subjektivne norme, vrednote) kot tudi poskus socialnega vplivanja. Ugotovila je, da na motivacijo za okolju prijazno vedenje bolj vplivajo notranji dejavniki (vedenjski nadzor, stališča in subjektivne norme) kot 
socialni dejavniki. Pomembni notranji dejavniki za okolju prijazno vedenje naj bi bile zlasti osebne norme, ki zajemajo občutek posameznikove odgovornosti za okolje, in biosferična vrednotna naravnanost. Negativen vpliv na okolju prijazno vedenje pa ima egoistična vrednotna usmeritev. Med socialne dejavnike, ki vplivajo na okolju prijazno vedenje, sodita višja izobrazba in znanje. Po vpeljavi strategij, s katerimi je avtorica želela spodbuditi okolju prijazno vedenje (nagrajevanje s praktičnim darilom, usmerjeno informiranje ter izobraževanje prek spletne strani in socialnih omrežij, zaveze k okolju prijaznem vedenju in opomniki), se je pokazal pomemben učinek znanja, vrednot in osebnih norm na okolju prijazno vedenje (racionalno porabo vode, varčevanje $z$ električno energijo in ravnanje $z$ odpadki). Rezultati raziskave se delno skladajo $\mathrm{z}$ avtoričinim predhodno zasnovanim sinteznim teoretskim modelom, ki je kombinacija Ajzenove teorije načrtovanega vedenja (Ajzen, 1991), Sternove teorije vrednot, prepričanj in norm (Stern, 2000) ter vpliva znanja. Avtorica zasnovanega modela ni preverila s strukturnim modeliranjem, zato bi bilo v prihodnje zanimivo izvesti tovrstno analizo. Pomanjkljivosti raziskave sta selektiven vzorec, pretežno sestavljen iz višje izobraženih prebivalcev, in posredno merjenje ravnanja $z$ električno energijo, vodo in odpadki (Polajnar Horvat, 2014). Kljub temu so rezultati raziskave primerljivi $\mathrm{z}$ dognanji dosedanjih raziskav $\mathrm{s}$ področja vrednot (npr. De Groot in Steg, 2008) in uporabe strategij za spodbujanje okolju prijaznega vedenja.

Število raziskav, ki se ukvarjajo s proučevanjem raznovrstnih ukrepov $\mathrm{k}$ spodbujanju okolju prijaznega vedenja, strmo narašča, pri čemer se raziskovalci poslužujejo različnih strategij, s katerimi želijo spodbuditi okolju prijazno vedenje. Uporabljene strategije so lahko predhodne ali posledične (Abrahamse, Steg, Vlek in Rothengatter, 2005). Za prve je značilno, da $\mathrm{z}$ njimi skušajo pred samim vedenjem vplivati na vedenjske determinante, ki naj bi se kasneje odražale v okolju prijaznejšem vedenju. Mednje sodijo strategija zavez, strategija postavljanja ciljev, strategija informiranja udeležencev in strategija modeliranja. Za strategijo zavez je značilno, da posameznik ustno ali pisno sklene, da bo ravnal okolju prijazneje (navadno na nekem specifičnem področju, npr. varčevanje z vodo). Strategija postavljanja ciljev pomeni, da si posameznik določi referenčno točko zmanjšanja nekega porabniškega vedenja oz. le-to namesto njega določi raziskovalec (npr. odstotek zmanjšanja porabe energije). Strategija informiranja udeležencev vključuje delavnice, medijske kampanje in usmerjeno (posamezniku prilagojeno) informiranje, strategija modeliranja pa temelji na principu modelnega učenja in posameznika preko modela seznanja s primeri okolju prijaznega vedenja. Posledične strategije raziskovalci vpeljujejo po tem, ko se pojavi okolju (ne)prijazno vedenje. Mednje sodita strategija nagrajevanja (npr. denarne spodbude ali praktična darila) in strategija povratnih informacij, ki jih udeleženci lahko dobijo kontinuirano, dnevno/tedensko/mesečno ali primerjalno. V primeru primerjalnih povratnih informacij raziskovalci učinkovitost posameznikovega vedenja prikažejo $\mathrm{v}$ odnosu do rezultatov ostalih udeležencev (Abrahamse idr., 2005). W. Abrahamse in sodelavci (2005) so po pregledu raziskav s področja zmanjševanja porabe energije ugotovili, da se $\mathrm{v}$ raziskavah $\mathrm{z}$ uporabljenimi predhodnimi strategijami glede na dolgoročnejši učinek najbolje obnese strategija zaveze, od posledičnih strategij pa naj bi bili najučinkovitejši strategija povratnih informacij in strategija nagrajevanja, ki pa ne zagotavlja dolgoročnejših učinkov.

Zaradi različnih mehanizmov delovanja strategij je pomembno tudi razločevanje med individualnimi strategijami (informiranje, individualne povratne informacije, postavljanje ciljev) in strategijami socialnega vplivanja (uporaba deskriptivnih in preskriptivnih socialnih norm, primerjalne povratne informacije, zaveze, vključevanje mnenjskega voditelja, socialno modeliranje). Rezultati metaanalize raziskav o učinkovitosti strategij za spodbujanje okolju prijaznega vedenja na različnih področjih (manjša poraba električne energije, vode, recikliranje, učinkovito prevažanje), izvedenih v državah zahodne kulture (večinoma $\mathrm{v}$ Združenih državah Amerike, na Nizozemskem in v Angliji), kažejo, da je skupni učinek strategij socialnega vplivanja v primerjavi s kontrolnimi skupinami majhen do srednji (Hedgesov $g=0,35)$, pri čemer je posamezno najučinkovitejša strategija vključevanje mnenjskega voditelja, ki po svoji socialni mreži širi informacije o pomenu okolju prijaznega vedenja (Hedgesov $g=0,82$ ). S srednje velikim učinkom sledita strategija javnih zavez in modeliranje (Hedgesov $g$ znaša 0,58 in 0,51), majhne učinke pa je pričakovati od strategij primerjalnih povratnih informacij in socialnih norm (Hedgesov $g=0,10-0,13$ ), kar avtorici pojasnjujeta s pojavom »bumerang učinka«, ko udeleženci, ki so predhodno porabili manj energije od ostalih, zaradi primerjalne informacije povečajo porabo energije. Primerjava strategij socialnega vplivanja in individualnih strategij je pokazala, da so učinkovitejše strategije socialnega vplivanja, vendar je učinek majhen (Abrahamse in Steg, 2013).

Rezultati metaanalize eksperimentalnih raziskav o ukrepih za spodbujanje okolju prijaznega vedenja Osbaldistona in Schotta (2012) kažejo, da med najbolj učinkovite strategije sodijo kognitivna disonanca, postavljanje ciljev, socialno modeliranje in opomniki (kratka pisna opozorila o okolju prijaznem vedenju). Avtorja poudarjata, da je učinkovitost ukrepov odvisna od vedenja, ki ga skušamo podkrepiti. Tako naj bi bila pri zmanjševanju porabe energije najučinkovitejša ukrepa socialno modeliranje in zaveze, pri spodbujanju ločevanja odpadkov pa nagrajevanje in strategija olajševanja (npr. lažje dostopni zabojniki za ločeno zbiranje odpadkov).

Avtorji obeh metaanaliz izpostavljajo, da raziskovalci v mnogih študijah (pogosto nenamerno) hkrati uporabijo različne strategije, zaradi česar je izračun ločenih učinkov nemogoč. Kljub temu sta Osbaldiston in Schott (2012) 
oblikovala preglednico najučinkovitejših združenih strategij, ki lahko pomaga pri načrtovanju učinkovitih intervenc k spodbujanju okolju prijaznega vedenja. Avtorji omenjenih metaanaliz $\mathrm{v}$ kritikah tudi poudarjajo, da je večina raziskav izvedena na nereprezentativnih vzorcih, ki so pogosto sestavljeni iz višje izobraženih in bolj motiviranih posameznikov, zaradi česar moremo njihove izsledke posploševati le z zadržki. Poleg tega rezultati kažejo, da so učinki uporabe strategij socialnega vplivanja različni za različne skupine udeležencev in so največji pri vzorcu zaposlenih, študentov, nato pri gospodinjstvih in kmetijah (Abrahamse in Steg, 2013). Avtorici sklepata, da na omenjene rezultate verjetno vpliva komunikacija med udeleženci in skupinska identifikacija, prave vzvode delovanja pa je treba še temeljiteje raziskati.

Predhodno navedene strategije so namenjene spodbujanju t. i. zasebnega okoljevarstva (Stern, 2000), ki je sicer dobrodošlo, a je z ozirom na seznam glavnih svetovnih onesnaževalcev manj učinkovito (Chawla in Flanders Cushing, 2007). Gardner in Stern (2002, v Chawla in Flanders Cushing, 2007) trdita, da je okoljevarstvo lahko uspešno le $\mathrm{v}$ primeru kolektivne akcije ljudi, ki izvajajo pritisk na vlade in industrijo. Kljub temu je spodbujanje zasebnega okoljevarstva pomembno, saj pomena okolju prijaznega vedenja vsakega posameznika ne moremo zanemariti. $\mathrm{V}$ raziskovanju bi bilo zato $\mathrm{v}$ prihodnje dobro posvetiti pozornost predvsem individualnim vedenjem, ki imajo največji negativni vpliv na okolje (Clayton, Litchfield in Geller, 2013). Prav tako se večina dosedanjih raziskav ukvarja predvsem z vedenji zmanjševanja, za katere je značilno, da jih morajo udeleženci izvajati več časa (npr. zmanjševanje porabe vode s krajšimi prhami, ščetkanje zob pri zaprti pipi itd.) (Abrahamse idr., 2005; Clayton idr., 2013) in so manj učinkovita od vedenj učinkovitosti, ki v enem samem dejanju in posledično krajšem času prispevajo k zmanjšanju ekološkega odtisa (npr. nakup okolju prijaznejšega avtomobila, energetska prenova objektov ipd.). $\mathrm{V}$ prihodnje bi se morali usmeriti $\mathrm{k}$ raziskovanju spodbujanja vedenj učinkovitosti in si prizadevati za uporabo pridobljenih spoznanj $\mathrm{v}$ vsakdanjem življenju. Pri tem je pomembna zlasti ciljna skupina, saj je aplikacija učinkovitejša $\mathrm{v}$ primeru vplivanja na organizacije kot na posameznika (Clayton idr., 2013). Pomembno vlogo na tem področju bi lahko prevzela zlasti psihologija organizacije. Zaradi relevantnosti okoljevarstvene teme $\mathrm{v}$ vsakdanjem življenju ljudi bi bilo zanimivo več poudarka nameniti tudi raziskovanju socialnih reprezentacij in $\mathrm{z}$ njimi povezane komunikacije o trajnostnem razvoju, kar bi lahko omogočilo dodatno razumevanje odnosa ljudi do okoljevarstva, denimo $\mathrm{v}$ primerih konfliktov interesov prebivalcev zaščitenih območij (Castro, 2006). Prav tako bi bilo zaradi naraščajočega števila uporabnikov spletnih socialnih omrežij (zlasti med mlajšimi posamezniki) zanimivo proučiti tudi njihov vpliv na posameznikov odnos do naravnega okolja.

\section{Okoljevarstvena psihologija v razvojni psihologiji}

Mlajše (in bodoče) generacije so tiste, ki bodo v prihodnje prevzele breme dosedanje degradacije okolja in velik del odgovornosti za ohranjanje okolja. V tem oziru so se raziskovalci osredotočili na razvoj okoljevarstvene naravnanosti pri posameznikih. V nadaljevanju prispevka predstavljam glavne ugotovitve raziskav $\mathrm{s}$ področja okoljevarstvene psihologije v razvojnopsihološkem okvirju, ki se večinoma dosledno ponavljajo skozi daljše časovno obdobje, obenem pa navajam tudi rezultate nekaterih novejših usmeritev $\mathrm{v}$ raziskovanju.

$\mathrm{V}$ retrospektivno zasnovanih študijah o dejavnikih, ki naj bi vplivali na razvoj okoljevarstvene naravnanosti pri aktivistih, so le-ti kot pobudo za svoje zavzemanje za ohranjanje naravnega okolja najpogosteje navajali zgodnje pozitivne izkušnje v naravi (npr. preko igre in raziskovanja) (Chawla, 1999; 2007; Chawla in Flanders Cushing, 2007; Wells in Lekies, 2006). Zgodnje preživljanje časa $\mathrm{v}$ naravi pa samo po sebi ni dejavnik skrbi za ohranjanje naravnega okolja, temveč je povezano z razvojem čustvene naklonjenosti do njega. Prav čustvena naklonjenost naj bi bila pomemben napovednik okolju prijaznega vedenja (Kals, Schumacher in Montada, 1999). Med ostale spodbudne dejavnike za razvoj okoljevarstvene naravnanosti se je uvrstil tudi vpliv staršev, učiteljev ali vrstnikov, nekateri posamezniki pa so se začeli zavzemati za ohranjanje okolja, ker so bili v preteklosti priče uničevanju (njim pomembnih delov) naravnega okolja (Chawla, 1999).

Zdi se, da v sodobni zahodni kulturi staršem vse pogosteje primanjkuje časa, da bi z otroki preživljali čas $\mathrm{v}$ naravi, zato imajo $\mathrm{v}$ zgodnejših razvojnih obdobjih pomembno vlogo pri razvijanju okoljske ozaveščenosti tudi vzgojiteljice. Njihov vpliv na otrokovo dojemanje naravnega okolja in skrbi zanj je manj raziskan, zato bi bilo omenjenemu področju dobro posvetiti večjo pozornost. Več poudarka bi bilo smiselno nameniti tudi kvalitativnemu in vzdolžnemu raziskovanju izkušenj otrok v zvezi z naravo in njihovega dojemanja naravnega okolja in skrbi zanj (Chawla in Derr, 2012; Clayton, 2012b). Kot možno izhodišče za nadaljnje raziskovanje L. Chawla in V. Derr (2012) navajata proučevanje načinov, kako otrokom iz urbanih območij približati naravo, tako da bi ob tem zmanjšali njihovo doživljanje strahu in nelagodja. Eden od možnih načinov bi lahko bila »tehnološka narava«. Nove tehnologije naj bi namreč omogočale lažji in hitrejši dostop do informacij o naravi in celo simulirale pravo naravno okolje (Myers, 2012). Rezultati raziskav kažejo, da je tehnološko posredovana narava vseeno boljša kot odsotnost stika $\mathrm{z}$ naravnim okoljem, a le-tega ne more docela nadomestiti (Kahn, Severson in Ruckert, 2009), kar bi bilo dobro upoštevati tudi pri načrtovanju programov okoljske vzgoje in izobraževanja, ki so jim avtorji v preteklosti namenili že veliko pozornosti (pregled v Chawla in Derr, 2012; Wals, 2012). 
$\mathrm{V}$ zadnjem obdobju se raziskovalci na področju razvoja okoljevarstvene naravnanosti ukvarjajo predvsem $\mathrm{z}$ razvojem okoljske identitete in $\mathrm{z}$ generativnostjo. $\mathrm{Na}$ področju okoljske identitete je še vedno potrebna zlasti razširitev razumevanja koncepta okoljske identitete $\mathrm{s}$ proučevanjem njenega razvoja in pomembnih dejavnikov, ki vplivajo na posameznikovo dojemanje naravnega okolja kot pomembnega dela sebstva. Okoljska identiteta naj bi se začela razvijati že v zgodnjem otroštvu preko prej omenjenih pozitivnih izkušenj $\mathrm{v}$ naravnem okolju, njen razvoj pa naj bi se nadaljeval v mladostništvu (Matsuba in Pratt, 2013). Raziskovalci so veliko pozornosti namenili razvoju okoljske identitete $\mathrm{v}$ okviru teorije pripovedne identitete. Posamezniki naj bi številne pozitivne ali negativne izkušnje $\mathrm{z}$ naravnim okoljem vključili v svojo pripovedno okoljsko identiteto, ki je del osebne zgodbe posameznika (Matsuba in Pratt, 2013). V študiji, v kateri so primerjali pripovedno okoljsko identiteto kanadskih okoljevarstvenih aktivistov in neaktivistov, so ugotovili, da so aktivisti dosegali višje rezultate pri pripovedni okoljski identiteti; njihove zgodbe o izkušnjah v naravnem okolju so bile namreč daljše in bolj premišljene, vsebovale so več podrobnosti, posamezniki pa so jim pripisovali večji pomen za svojo povezanost z naravo (Alisat, Norris, Pratt, Matsuba in McAdams, 2014). Pripovedna okoljska identiteta se je povezovala tudi z merama okoljske identitete in generativnosti, pri čemer je okoljska identiteta preko generativnosti napovedovala mero pripovedi o okolju (Alisat idr., 2014).

Eden od dejavnikov, ki so pomembni za posameznikovo odločitev o okoljevarstvu, naj bi bil dosežen identitetni status. V študiji, ki jo je s sodelavci zasnoval Matsuba (2012), so ugotovili, da identitetna zrelost preko generativnosti posredno napoveduje okoljevarstveno naravnanost in to ne glede na starostno skupino, v katero so se posamezniki uvrščali (bodisi na prehod v odraslost ali v srednjo odraslost). Prav pojav generativnosti $\mathrm{v}$ mladostništvu in na prehodu $\mathrm{v}$ odraslost pa je spremenljivka, ki ji raziskovalci v zadnjem obdobju posvečajo več pozornosti, saj lahko skrb za ohranjanje okolja prihodnjim generacijam razumemo kot generativno dejanje. V vzdolžni študiji so Jia, S. Alisat in Pratt (2014) ugotovili, da identitetna zrelost in vključenost $\mathrm{v}$ dejavnosti v skupnosti ob zaključku mladostništva pomembno sočasno napovedujeta generativno skrb, obenem pa se le-ta z leti viša, če so (bili) posamezniki vključeni v dejavnosti v skupnosti, ne pa tudi v primeru višje zrelosti identitete pri 32. letu. Višja generativna skrb na začetku prehoda $\mathrm{V}$ odraslost napoveduje izrazitejšo okoljsko pripovedno identiteto na začetku zgodnje odraslosti (Jia, Soucie, Alisat in Pratt, 2015). V vzdolžni študiji so namreč ugotovili, da so posamezniki, ki so na prehodu v odraslost razvili višjo generativno skrb, v zgodnji odraslosti v intervjuju poročali s pomensko polnejšimi in bolj živimi pripovedmi o okolju in sprožilnih dogodkih za usmeritev v okoljevarstvo. V prihodnje bi bilo smiselno proučiti vzdolžni odnos med razvojem okoljske identitete in različnimi vidiki generativnosti (Jia idr., 2015), na sploh pa bi bilo na področju okoljevarstvene psihologije v razvojni psihologiji dobro izvesti več vzdolžnih študij. Bolj poglobljeno bi se lahko osredotočili tudi na dejavnike, ki $\mathrm{v}$ mladostništvu in na prehodu $\mathrm{v}$ odraslost ovirajo okoljevarstveno naravnanost. Okoljevarstveni aktivizem bi lahko vključili v raziskave o prostovoljstvu, na podlagi spoznanj pa nadgradili prostovoljske projekte ter na ta način spodbujali generativne težnje posameznikov.

$\mathrm{Z}$ obdobjem prehoda $\mathrm{V}$ odraslost oz. $\mathrm{Z}$ zgodnjo odraslostjo se proučevanje razvojnih vidikov okoljevarstva nekako zaključi. Na tem področju primanjkuje raziskav s posamezniki v srednji-, še bolj pa pozni odraslosti. V okviru razvojne, okoljevarstvene in okoljske psihologije bi bilo smiselno več poudarka nameniti proučevanju vplivov narave na starostnike, ki so bili v tem oziru prikrajšani. Večina raziskav se namreč osredotoča le na številne pozitivne učinke narave na zdravje in razvoj otrok (pregled v Charles in Senauer, 2010). Izsledki kvazieksperimentalne študije avtorice I. Fjørtoft (2004) na primer kažejo na pozitiven učinek igre $\mathrm{v}$ naravi. Otroci, ki so bili leto dni vključeni v eno- do dvourno igro v bližnjem gozdu, so na gibalnem testu dosegali boljše rezultate v motoričnih sposobnostih, ravnotežju in koordinaciji kot kontrolna skupina otrok, ki se je igrala na običajnem igrišču. Prav tako naj bi se otroci pogosteje vključevali $\mathrm{v}$ funkcijsko, konstrukcijsko in simbolno igro $\mathrm{v}$ naravi, kjer je prisotno drevje in grmičevje, $\mathrm{v}$ primerjavi $\mathrm{z}$ igro na otroških igriščih, ki so navadno ploska, prekrita $\mathrm{z}$ asfaltom in otrokom ne nudijo zadostne stimulacije za raziskovanje okolja (Fjørtoft, 2004). Raziskavo navajam kot dober primer prepleta razvojne in okoljske psihologije, katere rezultate bi lahko uporabili na področju okoljevarstvene psihologije pri načrtovanju količine preživetega časa $\mathrm{v}$ naravnem okolju in na ta način pri otrocih spodbujali razvoj okoljevarstvene naravnanosti. Pri naslavljanju okoljevarstvenih vprašanj je namreč pomembno sodelovanje med psihološkimi panogami, kar naj bi omogočala prav okoljevarstvena psihologija. Vse bolj neizogibno pa postaja tudi interin multidisciplinarno povezovanje psihologije in drugih družboslovnih, naravoslovnih in tehničnih ved (Clayton idr., 2015).

\section{Zaključek}

S. Clayton je v sklepnem poglavju učbenika o okoljski in okoljevarstveni psihologiji zapisala, da so »okoljski problemi problemi človeštva« (Clayton, 2012b, str. 682), ne le zato, ker jih povzroča človek s svojim vedenjem, ampak zato, ker se posledice človeškega vedenja odražajo v okolju, ki vpliva na človeka, njegovo bivanje in blagostanje. Kljub naraščajoči okoljski problematiki v svetu in vplivom, ki jih ima na življenja ljudi, njeno proučevanje med slovenskimi psihologi ni najbolj poznano. $\mathrm{V}$ pričujočem prispevku sem zato predstavila novejše 
področje proučevanja recipročnega odnosa med človekom in naravo - okoljevarstveno psihologijo, katere glavni cilj je spodbuditi okolju prijazno vedenje in pripomoči $\mathrm{k}$ usmeritvi v trajnostni razvoj.

Zaradi aktualnosti problematike, s katero se okoljevarstvena psihologija ukvarja, število raziskav hitro narašča. V prispevek sem zato vključila le majhen del sicer obsežnega raziskovalnega področja. Osredotočila sem se na najbolj raziskani psihološki panogi v okviru okoljevarstvene psihologije - socialno in razvojno psihologijo, med kateri se vpletajo tudi spoznanja iz okoljske psihologije, kijeokoljevarstvenipsihologijinajbolj sorodna psihološka panoga. Glavna razlika med njima je prav ta, da okoljevarstvena psihologija ni psihološka panoga, temveč raziskovalno področje, ki združuje spoznanja različnih psiholoških panog in jih uporablja pri spodbujanja okoljevarstva. Okoljevarstvena psihologija iz socialne psihologije zajema spoznanja o okoljskih stališčih, vrednotah, identiteti in različnih strategijah vplivanja na okolju prijazno vedenje. Veliko raziskav so avtorji izvedli prav na zadnjem področju, zaradi česar sem se v prispevku osredotočila predvsem na učinkovite strategije, s katerimi so želeli spodbuditi vedenja zmanjševanja. V prihodnje bi bilo smiselno več pozornosti posvetiti spodbujanju vedenj učinkovitosti, zanimiva iztočnica za raziskovanje pa je tudi okoljska identiteta, vendar bo za začetek na področju okoljevarstvene psihologije najprej potrebno prirediti merske pripomočke. Nekaj potencialno uporabnih sem predstavila tudi $\mathrm{v}$ prispevku, $\mathrm{v}$ nadaljevanju katerega sem na področju okoljevarstvene psihologije $v$ razvojni psihologiji predstavila pomen preživljanja časa $\mathrm{v}$ naravi za razvoj okoljevarstvene naravnanosti posameznika. Vzhajajoča raziskovalna iztočnica $\mathrm{v}$ okviru razvojne psihologije je tudi generativna skrb v mladostništvu in na prehodu $\mathrm{v}$ odraslost, več pozornosti pa bi bilo $\mathrm{v}$ prihodnje dobro posvetiti tudi vplivom naravnega okolja na posameznike v pozni odraslosti.

V prispevku sem zapostavila vidike okoljevarstvene psihologije $\mathrm{v}$ ostalih psiholoških panogah, ki so prav tako pomembne za razumevanje človekovega odnosa z naravnim okoljem. Psihologija dela in organizacije, kognitivna psihologija in pozitivna psihologija, če jih naštejem le nekaj, nudijo zanimiva izhodišča za raziskovanje, ki pa ne bi smelo (p)ostati glavni namen delovanja psihologov. Enakovredno skrb bi bilo namreč treba posvetiti tudi aplikaciji spoznanj, k čemur bi lahko $\mathrm{z}$ aktivnim udejstvovanjem na področju okoljevarstvene psihologije v sodelovanju s strokovnjaki drugih disciplin doprinesli tudi slovenski psihologi.

\section{Literatura}

Abrahamse, W. in Steg, L. (2013). Social influence approaches to encourage resource conservation: A meta-analysis. Global Environmental Change, 23, 1773-1785.
Abrahamse, W., Steg, L., Vlek, C. in Rothengatter, T. (2005). A review of intervention studies aimed at household energy conservation. Journal of Environmental Psychology, 25, 273-291.

Ajzen, I. (1991). The theory of planned behavior. Organizational Behaviour and Human Decision Processes, 50, 179-211.

Alisat, S., Norris, J. E., Pratt, M. W., Matsuba, M. K. in McAdams, D. P. (2014). Caring for the Earth: Generativity as a mediator for the prediction of environmental narratives from identity among activists and nonactivists. Identity: An International Journal of Theory and Research, 14(3), 177-194.

APA Division 34: Society for environmental, population and conservation psychology. (2015). Conservation psychology. Pridobljeno 25. 7. 2015, s http://www. apadivisions.org/division-34/interests/conservation/

Blair, L. (2011). Ecopsychology and the person-centred approach: Exploring the relationship. Counselling Psychology Review, 26(1), 43-52.

Brook, A. T. (2001). What is »conservation psychology?« Population and Environmental Psychology Bulletin, 27(2), 1-2.

Castro, P. (2006). Applying social psychology to the study of environmental concern and environmental worldviews: Contributions from the social representations approach. Journal of Community \& Applied Social Psychology, 16, 247-266.

Castro, P. in Lima, M. L. (2001). Old and new ideas about the environment and science: An exploratory study. Environment and behavior, 33(3), 400-423.

Charles, C. in Senauer, A. (2010). Health benefits to children from contact with the outdoors and nature. Pridobljeno s strani http://www.childrenandnature. org/downloads/C\&NNHealthBenefits.pdf

Chawla, L. (1999). Life paths into effective environmental action. The Journal of Environmental Education, $31(1), 15-26$.

Chawla, L. (2007). Childhood experiences associated with care for the natural world: A theoretical framework for empirical results. Children, Youth and Environments, 17(4). 144-170.

Chawla, L. in Flanders Cushing, D. (2007). Education for strategic environmental behavior. Environmental Education Research, 13(4), 437-452.

Chawla, L. in Derr, V. (2012). The developement of conservation behaviors in childhood and youth. V S. D. Clayton (ur.), The Oxford handbook of environmental and conservation psychology (str. 527-555). New York: Oxford University Press.

Cialdini, R. (2003). Crafting normative messages to protect the environment. Current Directions in Psychological Science, 12, 105-109.

Clayton, S. D. (2003). Environmental Identity Scale [Zapis v podatkovni zbirki]. Pridobljeno iz zbirke PsycTESTS. 
Clayton, S. D. (2012a). Environment and identity. V S. D. Clayton (ur.), The Oxford handbook of environmental and conservation psychology (str. 164-180). New York, NY, ZDA: Oxford University Press.

Clayton, S. D. (2012b). Conclusion: Directions for the future. V S. D. Clayton (ur.), The Oxford handbook of environmental and conservation psychology (str. 673-683). New York: Oxford University Press.

Clayton, S. in Brook, A. (2005). Can psychology help save the world? A model for conservation psychology. Analyses of Social Issues and Public Policy, 5(1), 87-102.

Clayton, S. D., Devine-Wright, P., Swim, J., Bonnes, M., Steg, L., Whitmarsh, L. in Carrico, A. (2015, 6. julij). Expanding the role for psychology in addressing environmental challenges. American Psychologist. Pridobljeno s strani http://dx.doi. org/10.1037/a0039482

Clayton, S., Litchfield, C. in Geller, S. E. (2013). Psychological science, conservation, and environmental sustainability. Frontiers in Ecology and the Environment, 11(7), 377-382.

Clayton, S. in Myers, G. (2009). Conservation psychology: Understanding and promoting human care for nature. Chichester, Velika Britanija: Wiley-Blackwell.

Clayton, S. D. in Saunders, C. D. (2012). Introduction: Environmental and conservation psychology. V S. D. Clayton (ur.), The Oxford handbook of environmental and conservation psychology (str. 1-7). New York, NY, ZDA: Oxford University Press.

De Groot, J. in Steg, L. (2008). Value orientations to explain beliefs related to environmental significant behavior: How to measure egoistic, altruistic, and biospheric value orientations. Environment and Behavior, 40(3), 330-354.

Dunlap, R. E. in Van Liere, K. D. (1978). The »new environmental paradigm «: A proposed measuring instrument and preliminary results. Journal of Environmental Education, 9, 10-19.

Dunlap, R. E., Van Liere, K. D., Mertig, A. G., in Emmet Jones, R. (2000). Measuring endorsement of the new ecological paradigm: A revised NEP scale. Journal of Social Issues, 56, 425-442.

Fjørtoft, I. (2004). Landscape as playscape: The effects of natural environments on children's play and motor development. Children, Youth and Environments, 14(2), 21-44.

Gabrovšek, K. (2011). Ljudje z naravo, narava za ljudi. Biotska pestrost je naše življenje. Ljubljana, Slovenija: Zavod Republike Slovenije za varstvo narave.

Gifford, R. (2002). Environmental psychology: Principles and practice (3. izd.). Colville, WA, ZDA: Optimal Books.

Gifford, R. in Sussman, R. (2012). Environmental attitudes. V S. D. Clayton (ur.), The Oxford handbook of environmental and conservation psychology (str. 65-80). New York, NY, ZDA: Oxford University Press.
Goldstein, N. J., Cialdini, R. B. in Griskevicius, V. (2008). A room with a viewpoint: Using social norms to motivate environmental conservation in hotels. Journal of Consumer Research, 35, 472-482.

Göckeritz, S., Schultz, W. P., Rendón,T. Cialdini, R. B., Goldstein, N. J. in Griskevicius, V. (2010). Descriptive normative beliefs and conservation behavior: The moderating roles of personal involvement and injunctive normative beliefs. European Journal of Social Psychology, 40, 514-523.

Hawcroft, L. J. in Milfont, T. L. (2009). The use (and abuse) of the new environmental paradigm scale over the last 30 years: A meta-analysis. Journal of Environmental Psychology, 30, 143-158.

Hoelterhoff, M. (2010). Saving ecopsychology from itself: The need for scientific enquiry. History \& Philosophy of Psychology, 12(1), 63-68.

Jia, F. Alisat, S. in Pratt, M. W. (2014). The relationship between identity, community involvement and generativity in a longitudinal study. Referat, predstavljen na simpoziju pozitivne psihologije $\mathrm{v}$ Ottawi, Kanada. Pridobljeno na spletni strani http:// www.positivepsychologycanada.com/Resources/ Documents/Fanli,_CPP,July,\%202014.pdf

Jia, F., Soucie, K., Alisat, S. in Pratt, M. W. (2015). Sowing seeds for future generations: Development of generative concern and its relation to environmental narrative identity. International Journal of Behavioral Development. 1-5.

Kahn, P. H., Severson, R. L. in Ruckert, J. H. (2009). The human relation with nature and technological nature. Current Directions in Psychological Science, 18(1), 37-42.

Kals, E., Schumacher, D. in Montada, L. (1999). Emotional affinity toward nature as a motivational basis to protect nature. Environment and Behavior, 31(2), 178-202.

Mascia, M. B., Brosius, J. P., Dobson, T. A., Forbes, B. C., Horowitz, L., McKean, M. A. in Turner, N. J. (2003). Conservation and the social sciences. Conservation Biology, 17(3), 649-650.

Matsuba, M. K. in Pratt, M. W. (2013). The making of an environmental activist: A developmental psychological perspective. New Directions for Child and Adolescent Development, 142, 59-74.

Matsuba, M. K., Pratt, M. W., Norris, J. E., Mohle, E., Alisat, S. in McAdams, D. P. (2012). Environmentalism as a context for expressing identity and generativity: Patterns among activists and uninvolved youth and midlife adults. Journal of Personality, 80(4), 1091-1115.

Milfont, T. L. in Duckitt, J. (2010). The environmental attitudes inventory: A valid and reliable measure to assess the structure of environmental attitudes. Journal of Environmental Psychology, 30, 80-94.

Myers, O. E. (2012). Children and nature. V S. D. Clayton (ur.), The Oxford handbook of environmental and conservation psychology (str. 113-127). New York, NY, ZDA: Oxford University Press. 
Onwezen, M. C., Antonides, G. in Bartels, J. (2013). The norm activation model: An exploration of the functions of anticipated pride and guilt in pro-environmental behaviour. Journal of Economic Psychology, 39, 141-153.

Osbaldiston, R. in Schott, J. P. (2012). Environment sustainability and behavioral science: Metaanalysis of proenvironmental behavior experiments. Environment and Behavior, 44, 257-299.

Oskamp, S. (2000). Psychological contributions to achieving an ecologically sustainable future for humanity. Journal of Social Issues, 56(3), 373-390.

Polajnar Horvat, K. (2014). Vloga socialnih dejavnikov pri razvoju okoljske ozaveščenosti in spreminjanju okoljskega vedenja. Doktorska disertacija, Ljubljana: Univerza v Ljubljani, Filozofska fakulteta.

Saunders, C. D. (2003). The emerging field of conservation psychology. Human Ecology Review, 10(2), 137-149.

Sawitri, D. R., Hadyijanto, H. in Hadi, S. P. (2015). Proenvironmental behavior from a socialcognitive theory perspective. Procedia Environmental Sciences, 23, $27-33$.

Schwartz, S. H. (1994). Are there universal aspects in the structure and contents of human values? Journal of Social Issues, 50(4), 19-45.

Sommer, R. (2000). Discipline and field of study: A search for clarification. Journal of Environmental Psychology, 20, 1-4.

Steg, L. in de Groot, J. I. M. (2012). Environmental values. V S. D. Clayton (ur.), The Oxford handbook of environmental and conservation psychology (str. 8192). New York, NY, ZDA: Oxford University Press.

Steg, L., Perlaviciute, G., Van der Werff, E. in Lurvink, J. (2014). The significance of hedonic values for environmentally relevant attitudes, preferences, and actions. Environment and Behavior, 46(2), 163-192.

Stern, P. C. (2000). Toward a coherent theory of environmentally significant behavior. Journal of Social Issues, 56(3), 407-424.

Stern, P., Dietz, T., Abel, T., Guagnano, G. A. in Kalof, L. (1999). A value-belief-norm theory of support for social movements: The case of environmentalism. Human Ecology Review, 6(2), 81-97.

Van der Werff, E., Steg, L. in Keizer, K. (2014). I am what I am, by looking past the present: The influence of biospheric values and past behavior on environmental self-identity. Environment and Behavior, 46(5), $626-657$.

Wals, A. E. J. (2012). Learning our way out of unsustainability: The role of environmental education.V S. D. Clayton (ur.), The Oxford handbook of environmental and conservation psychology (str. 628-644). New York: Oxford University Press.

Wells, N. in Lekies, K. (2006). Nature and the life course: Pathways from childhood nature experiences to adult environmentalism. Children, Youth, and Environments, 16(1), 1-24. 